\title{
A PRELIMINARY INVESTIGATION OF NIGERIAN Gmelina arborea AND Bambusa vulgaris FOR PULP AND PAPER PRODUCTION
}

\author{
Mayowa Akeem Azeez ${ }^{1, \$}$, Jerome E. Andrew ${ }^{2}$, B. Bruce Sithole ${ }^{3}$
}

\begin{abstract}
Two common Nigerian-grown biomasses, gmelina (Gmelina arborea) and bamboo (Bambusaa vulgaris) have been pulped and their fibre characteristics and paper properties examined. The results of their chemical compositions showed some fair similarities. The amount of glucose in the pulps of both biomasses indicated their suitability as lignocellulosic materials for pulping. Their pulp yield ranged between 48,0-54,1\%, which fell within the acceptable range for good pulpwoods. The analysis of their fibre dimensions revealed that bamboo fibre has a wider fibre length distribution and higher fine length content. Gmelina and bamboo had weighted mean fibre lengths of 0,93 and 2,07 mm and mean fibre widths of 24,1 and $16,9 \mu \mathrm{m}$, respectively. The Runkel ratios of the samples were 0,4 (gmelina) and 0,9 (bamboo): this is indicative of their suitability for paper making. Mechanical properties of handsheets obtained from gmelina compared fairly well with South African pulpwoods (Eucalyptus grandis and Pinus paluta). Bamboo exhibited better tear index values than these woods but with lower sheet density and tensile index. These properties were significantly improved in handsheets obtained from blends of gmelina and bamboo, raising the prospect of producing paper from blends of both raw materials in Nigeria.
\end{abstract} index.

Keywords: Bamboo, cellulose, fibre, gmelina, hemicellulose, Kraft pulp, tear index, tensile

\section{INTRODUCTION}

Inadequacy of suitable local pulps is amongst the major problems confronting the development of the paper industry in Nigeria. This challenge has contributed to the collapse of the three integrated pulp and papermaking mills in the country. Prior to their closure, the mills, namely Nigerian Paper mill, Jebba, Nigeria Newsprint Manufacturing Company, Oku Iboku and Iwopin Pulp and Paper Company, had produced papers for the Nigerian market. The importation of newsprint and writing papers into Nigeria was at the lowest around 1990 when two of the companies were operating at their optimum capacity (Ogunwusi 2012). These paper mills were designed to utilize mixtures of short and long fibre pulps. However, there is a shortage of the pulps, especially the long fibre in Nigeria. This fibre, usually obtained from softwoods, is not readily available in Nigeria. Likewise, the local supplies of short fibres from hardwoods are barely adequate. As a result, the local mills largely depended on imported pulps for paper production, to meet their production demands. These complications amplified the rise in the cost of paper production to the extent that the importation of finished paper products was more cost effective and profitable than local production. Inevitably, this led to the demise of these mills around 1996 (RMRDC 2010).

\footnotetext{
${ }^{1}$ Department of Chemistry, Ekiti State University, Ado-Ekiti, Nigeria. mayowa.azeez@eksu.edu.ng

${ }^{2}$ Forestry and Forest Products Research Centre, CSIR Natural Resources and the Environment, Durban, South Africa. JAndrew@csir.co.za ${ }^{3}$ Forestry and Forest Products Research Centre, University of KwaZulu-Natal/CSIR Natural Resources and the Environment, Durban, South Africa. bsithole@csir.co.za

•Corresponding author: mayowa.azeez@eksu.edu.ng
}

Received: 30.12.2014 Accepted: 5.10.2015 
Apart from the loss of jobs as a result of the mill closures, the $100 \%$ importation of paper products has further compounded the economic woe of the country. Nigeria, with a population of over 160 million people, has many formal and informal economic sectors with huge demand for paper products. According to the Nigerian Raw Materials Research and Development Council (RMRDC 2009), the statistics of demand and supply of major raw materials for the pulp and paper sector in 2005 indicated a huge supply gap. With the exception of recycled waste paper, which accounted for only $26 \%$ of fibre required for the production of tissue papers in 2005, long and short fibre pulps, Kraft and fluting, and newsprints papers, all totalling over 700000 tonnes, were imported (RMRDC 2009).

In addressing the problem of capital flight and loss of jobs in the pulp and paper sector, there is a need for improved local capacities for the production of suitable pulps. The use of fast growing and locally available woody and non-woody biomass, suitable for pulping and paper making has been suggested as a remedy (Udohitinah and Oluwadare 2011). Since the old paper mills in Nigeria are capable of using mixtures of short and long fibres, combinations of two or more fibres from sustainable pulps is an alternative means of manufacturing papers from locally sourced pulp fibres.

Attempts have been made at investigating possible woody and non-woody plants that have the potential for the production of pulps in Nigeria (Odeyemi 1968, Kpikpi 1992, Ogunkunle and Oladele 2008, Ogunkunle 2010, Akpakpan et al. 2011, Emerhi 2012). In the work of Ndukwe et al. (2009), twenty indigenous hardwood samples were investigated for their suitability in pulping for papermaking using the Kraft pulping process. The investigation revealed that Milicia excelsa produced the lowest pulp yield of 35\%. A mean yield of 50\% was obtained for the pulps of Terminalia superba and Symphona globulifera. However, most of the investigated samples were commercial woods with huge demand for timbering. Whilst the fibre lengths of their pulps were not analysed in the work, conclusions on their suitability for pulping was drawn based on their chemical characteristics obtained from the infrared analysis of the fibres. Steculia is the family of one of the common hardwoods found in Nigeria. Ogunwusi (2002), identified Steculia setigera as a possible raw material for papermaking based on its fibre length of $2,41 \mathrm{~mm}$. Steculia oblonga investigated by Osadare (1997), using Kraft pulping was found to have a slightly shorter fibre length than S. setigera. Its average fibre length of 2,07 $\mathrm{mm}$ was noted to be better than fibres from many tropical hardwoods. The strength properties of its unbleached Kraft paper was reported to be relatively comparable with that of commercial Kraft paper produced at Nigerian mills (Osadare 1997, Ogunwusi 2012).

Similarly, investigations carried out on some non-woody plants in Nigeria revealed some of them to be promising resources for the production of long fibre (Fuwape 1993, Raji 2007, Akpabio and Akpakpan 2012). Using kenaf (Hibiscus cannabinus), Udohitinah and Oluwadare (2011), have reported fibre length $(2,90 \mathrm{~mm})$, fibre diameter $(28,16 \mu \mathrm{m})$, lumen width $(6,08 \mu \mathrm{m})$ and Runkel ratio $(0,76)$ of the obtained pulp. Fibre dimensions are important indices in evaluating the suitability of a fibre for pulp and papermaking. The reported fibre length falls within the range of 2,7 - 4,6 mm reported for softwood-derived fibres (Ates et al. 2008). The prospect of pulping indigenous bamboo using the soda pulping process has also been investigated by Ogunsile and Uwajeh (2009). The optimum yield of $40,5 \%$ was enhanced to $51,5 \%$ by the addition of $60 \%$ butanol to the cooking liquor. The fibre dimensions measured from the pulp included fibre length $(2,32-2,92 \mathrm{~mm})$, fibre diameter $(15,5-18,8$ $\mu \mathrm{m})$ and lumen width $(3,3-4,4 \mu \mathrm{m})$. It was noted that the age of the sample played no significant role in pulp yields and properties.

Amongst hardwoods found in forest reserves in Nigeria is gmelina (Gmelina arborea). Various plantations of the tree were established mostly in southern Nigeria about 50 years ago, as possible pulp wood for paper industries. The plantations are estimated at 112000000 ha (Onyekwelu 2004). Many of these plantations have almost outgrown their usefulness since the closure of the paper mills. In recent times, the trees are being harvested to balance the supply of timbers and for other economic benefits. G. arborea is noted to be an ideal pulpwood (Palmer 1973, Ogbonnaya 1993, Olatunji 1999, Dvorak 2004) . It has a rapid growth rate, low extractives content and basic wood density, and a good fibre length. The wood density of matured gmelina is roughly $410 \mathrm{~kg} / \mathrm{m}^{3}$ (Dvorak 2004). Basic wood density is an important parameter in pulping. Its variation alters the pulp yield as well as the specific energy of pulping process (Dvorak 2004). It has been noted that wood density is an indicator of energy consumption during pulping ( $\mathrm{Li}$ et al. 2011). Furthermore, with a 10 to $30 \%$ annual increase in biomass compared to 2 to $5 \%$ for trees, bamboo offers great potential for industrial utilisation and it has been 
suggested as possible replacement for the production of fibre in place of softwoods (Ogunwusi 2011). This plant has largely been under-utilized for many industrial processes in Nigeria. It is mostly harvested by locals and used as structure supports at building construction sites. Meanwhile, the biomass has become popular as a veritable raw material in the production of pulp and papermaking in India, China and Malaysia, with China alone responsible for two-thirds of world production of pulp from the plant (Mân Vu et al. 2004, Khristova et al. 2006). Also, bamboo is a fast growing and high yielding perennial plant. Compared to 20-40 years for the maturation of hardwoods, it can be harvested in 3 to 5 years. Several of its species such as Bambusaa vulgaris, B. arundinacea, and B. tulda are found abundantly in Nigeria. The $B$. vulgaris maintains a ubiquitous presence in the southern part of Nigeria. Some physical and mechanical properties of different bamboos have been evaluated (Ogunwusi 2011). With the density range of 500 to $800 \mathrm{~kg} / \mathrm{m}^{3}$, this biomass fall within basic density values of most softwoods and is therefore an acceptable raw material for pulping (Rowell 2005). The preferred range for wood density in the pulp and paper industry is between $400-600 \mathrm{~kg} / \mathrm{m}^{3}$ (Downes et al. 1997).

While some studies have been carried out on the pulping of Nigerian-grown G. arborea (Ogunkunle 2010), only a few studies on the production of pulps from the Nigerian indigenous bamboo are found in the literature. And most of these studies were limited to preliminary studies of the biomass's suitability for pulping. Investigation of their potentials as pulpwoods using Kraft pulping as well as their fibre and paper properties have rarely been explored. The main objective of this study therefore was to investigate the pulp and papermaking properties of Nigerian-grown G. arborea and B. vulgaris using the Kraft pulping process. The Kraft method of pulping has been chosen because unlike other methods of pulping, it is not limited by the presence of high extractives content, a common feature of African biomasses (Fengel and Wegener 1984). Fibre blending of both samples was also carried out to compare their paper making properties.

\section{MATERIALS AND METHODS}

\section{Material}

A $1,4 \mathrm{~m}$ billet of Gmelina arborea measuring $45 \mathrm{~cm}$ in diameter was obtained from an approximately 12 years old tree harvested from the forest reserve plantation along Ekiti State Government House, Ado Ekiti $\left(7,62^{\circ} \mathrm{N} ; 5,22^{\circ} \mathrm{E}\right)$, Nigeria. The billet was sampled just below the crown of the tree. It was hand debarked using a cutlass. Similarly, eight billets of B. vulgaris trunks, measuring $4,5 \mathrm{~cm}$ in diameter and $1,2 \mathrm{~m}$ in length were harvested from a large natural plantation located along Ado-Afao Road, Ado Ekiti $\left(7,63^{\circ} \mathrm{N} ; 5,22^{\circ} \mathrm{E}\right)$. These samples were also obtained from the trunk just below the crown. Both samples were shipped to the CSIR's Forestry and Forest Products Research Centre in South Africa for further processing.

\section{Kraft Pulping}

The billets were chipped using a 38" diameter, horizontal feed disc chipper (Precision Huskey Corporation, Alabama, USA) and the chips were screened in the laboratory using a vibratory chip screener to remove knots, bark, dirt, rot and any over- and under-sized material. Chips with a thickness between 3-8 mm were selected for pulping. Prior to pulping, the chips were air-dried for 2-3 weeks to reach equilibrium moisture content with the atmosphere. The moisture content of the chips was determined by drying representative samples, in an oven set at $105^{\circ} \mathrm{C}$, to constant mass.

Pulping was carried out (in triplicate), in electrically heated rotating digesters using the Kraft process. Eight hundred grams oven-dried (O.D) equivalent chips per cook were pulped using the conditions summarized in Table 1. During pulping, the moisture content of the chips was taken into account in order to maintain a constant liquor-to-wood ratio of 4,5:1. The cooked chips were washed with tap water, under high pressure, through a 10 -mesh screen $(1,7 \mathrm{~mm})$ onto a 200 -mesh $(75 \mu \mathrm{m})$ screen to separate the fibres from the rejects. The screenings remaining on the 10-mesh screen were considered as rejects. The pulp remaining on the 200 -mesh screen was placed into a cotton bag and de- 
watered by spin drying for 10 minutes. The moisture content of the pulp was determined according to the TAPPI standard method T550 om-93 (TAPPI 1995). The rejects remaining on the 10-mesh screen were oven-dried at $105 \pm 2^{\circ} \mathrm{C}$ to constant mass. The screened pulp and rejects were weighed and expressed as a percentage of their O.D mass over the O.D mass of chips pulped to give the percent screened pulp yield and percent rejects.

Table 1. Kraft pulping conditions.

\begin{tabular}{ll}
\hline Sulphidity & $25 \%$ \\
Mass of O.D chips & $800 \mathrm{~g}$ \\
Active alkali (as $\mathrm{Na}_{2} \mathrm{O} / \mathrm{O} . \mathrm{D}$ chips) & $18 \%$ \\
Liquor-to-wood ratio & $4,5: 1$ \\
Pulping temperature & $170^{\circ} \mathrm{C}$ \\
Time from ambient to maximum temperature & $90 \mathrm{~min}$ \\
Time at maximum temperature & 30 and $70 \mathrm{~min}$ \\
Target Kappa number & 20 \\
\hline Chemical analysis of wood and pulp &
\end{tabular}

Representative samples of chips of each biomass type were randomly taken. The chips were thoroughly examined to ensure that they were free of bark, knots, tension and compression wood. The conversion of the chips into sawdust for chemical analysis involved a three-step procedure in which the chips were first passed through a hammer-mill and then a Wiley mill, before finally being screened into the different particle size fractions using a vibratory screener. According to TAPPI standard method T257 (TAPPI 2002b), only sawdust that passed through the 40 mesh $(0,4 \mathrm{~mm})$ screen was used in the chemical analysis.

The relative amounts of the major constituent monosaccharides were determined by acid hydrolysis of the wood or pulp TAPPI T249 (TAPPI 1999a), followed by separation using high performance anion exchange chromatography (HPAEC) coupled with pulsed ampherometric detection (PAD). Lignin in the wood and pulp was determined using a modification of the TAPPI standard method T249 (TAPPI 1999a), in which the hydrolysate from the acid hydrolysis step used in the determination of the monosaccharides, was quantitatively filtered under vacuum through a $0,45 \mu \mathrm{m}$ filter paper. The material remaining on the filter paper was defined as acid insoluble Klason lignin. The Kappa number of the pulps were measured using TAPPI T236 (TAPPI 2006a) and the pulps intrinsic viscosity was measured using SCAN-CM 15:88.

\section{Physical properties of pulp}

Pulp quality was assessed by preparing and testing handsheets. Pulps were beaten in a PFI mill at $10 \%$ consistency for between 1000 and 5000 revolutions depending on the pulp type. Unbeaten pulps ( 0 revolutions) were used as controls. The freeness of the pulps at each level of beating was determined according to the Canadian Standard Freeness (CSF) method using the TAPPI standard method T227 (TAPPI 1999b). Handsheets with a basis weight of $60 \mathrm{~g} / \mathrm{m}^{2}$ were prepared on a Rapid Köthen sheet forming machine using a combination of the TAPPI standard method T205(TAPPI 1988) and the ISO standard method ISO 5269-1(ISO 2005). This procedure involved one pressing and heating drying of the handsheets. Ten handsheets per level of beating were prepared and allowed to condition in an atmosphere controlled at $23 \pm 1{ }^{\circ} \mathrm{C}$ and $50 \pm 2 \%$ relative humidity for at least 24 hours before testing for stretch (TAPPI T494)(TAPPI 2006b) and burst (TAPPI T403)(TAPPI 2002a), tear (TAPPI 414, TAPPI 2004a) and tensile (TAPPI T494, TAPPI 2006b) strengths. Pulp brightness was measured using a Technidyne Colour Touch ISO PC Model that conformed to ISO 2469, 2470, and other standards. Pulp quality of blends of the two fibre types were undertaken by individually beating the pulp fibres to approximately $430-450 \mathrm{CSF}$ and then combining the individual fibre types in varying ratios before producing handsheets for testing. 


\section{RESULTS AND DISCUSSION}

\section{Composition of raw materials}

Pulping efficiency can be significantly influenced by the composition of wood constituents (Silva et al. 2012). Results of various compositional physico-chemical analyses of investigated samples are shown in Table 2. The hydrophilic extractive contents of wood and plants samples were determined by the extraction of samples with hot water. A fraction of sample hemicellulose may be removed alongside with the lipophilic extractives such as phenolic acids, flavonoids, sterols and stilbenes. The result of extraction with hot water indicates that about $5 \mathrm{wt} . \%$ of bamboo was extractable in hot water, whereas only a third of gmelina was extractable. Incidentally, both samples contain the same amount of lipophilic extractives. This extractive fraction was obtained using toluene: ethanol mixture (2:1) according to TAPPI 204 (TAPPI 2004b). Woods with low extractives content are more desirable as pulpwood as they require less cooking chemicals and shorter pulping times, compared to high extractives wood. In addition, the presence of high lipophilic extractives in pulpwood causes pitch deposition problems (Back and Allen 2000; del Río et al. 2000). In the same vein, it also causes the reduction in pulp strength and pulp water retention capacity. The extractive contents of both samples, when compared to that of pine and eucalyptus (1,5 - 6\%) (Fengel and Wegener 1984) fall within the acceptable range for paper production.

The hemicelluloses content of bamboo contains more xylose and arabinose than gmelina. Generally, the proportion of various monosaccharides in the bamboo sample bears typical trait of hardwood hemicellulose. For instance, the concentration of mannose in both samples nearly ties and ranks next to xylose, which constitutes about 80 relative percentage of hemicellulose in both samples. The removal of a large amount the hemicellulose from pulp is desirable in the production of dissolving pulp where pure cellulose is desired. Its presence has been noted to cause problems in filtration process (Hocking 2005). But when Kraft pulping is employed, as in this work, hemicellulose retention is anticipated as it affects pulp yield and strength properties (amongst others). Cellulose contents of 51,25 wt. \% and 48,88 wt. \% and Klason lignin (acid insoluble lignin) of 29,05 wt. \% and 27,21 wt. \% were observed in extractive-free dry mass of gmelina and bamboo respectively. These values are in close agreement with values reported in the literature (Sosanwo and Lindberg 1975, Fuwape 1989, Mân Vu et al. 2004, Li et al. 2007).

The results of the chemical characterization of pulps of samples, obtained from trial with a cooking time of 70 minutes, are shown in Table 2. It can be observed that the delignification of bamboo was easier under the specified pulping conditions than that of gmelina. About $91 \%$ of the original lignin in bamboo was removed through Kraft pulping, compared to around $87 \%$ removal in gmelina pulp. The amounts of cellulose in pulps of both samples are identical. Based on the similarity in their cooking condition, these results illustrate the possibility of co-cooking of these samples. Runge et al. (2014), have observed that co-cooked 25/75 bamboo/poplar just like 25/75 bamboo/eucalyptus yielded good pulps. The bamboo pulp contained slightly higher hemicellulose remnant than gmelina. The ratio of syringyl to guaiacyl $(\mathrm{S} / \mathrm{G})$ in pulpwood is an important parameter employed in predicting pulp yield and the amount alkali required in Kraft cooking (Silva et al. 2012). The S/G value of gmelina was slightly higher than bamboo's. It has been noted that the predominance of syringyl over guaiacyl in woods promotes high pulp yield and such biomass are easy to be delignified (Nunes et al. 2010). 
Table 2. Chemical composition of Gmelina arborea and Bambusa vulgaris wood and pulp samples.

\begin{tabular}{lrrrr} 
& \multicolumn{2}{c}{ Wood } & Pulp \\
\hline & G. arborea & B. vulgaris & G. arborea & B. vulgaris \\
\hline Hot water extractives, wt.\% & 1,78 & 5,32 & & \\
Solvent extractives, wt.\% & 3,38 & 3,38 & & \\
Cellulose, wt.\% & 51,25 & 48,88 & & \\
Hemicellulose, wt.\% & & & & \\
$\quad$ Arabinose & 0,33 & 1,04 & 0,00 & 1,09 \\
$\quad$ Galactose & 0,64 & 0,34 & 0,00 & 0,20 \\
$\quad$ Glucose & 51,35 & 48,94 & 78,19 & 78,59 \\
$\quad$ Xylose & 10,16 & 15,86 & 10,95 & 16,41 \\
$\quad$ Mannose & 2,01 & 2,34 & 0,75 & 1,47 \\
Acid insoluble lignin, wt.\% & 29,05 & 27,21 & 6,41 & 2,68 \\
Acid soluble lignin, wt.\% & 1,99 & 2,30 & 0,90 & 0,97 \\
S/G ratio & 1,83 & 1,46 & & \\
\hline
\end{tabular}

Mean values from duplicate analyses are reported.

\section{Pulp properties}

The results of average pulp yields from duplicate pulping experiments are shown in table 3. Pulping was carried out using typical conditions for eucalypts but with varying $\mathrm{H}$-factors to attain a constant Kappa number. Starting with a cooking time of 70 minutes, the total yield of gmelina was $5 \%$ more than bamboo's. The observation fairly corresponds with the difference in cellulose contents of both samples. Typically, pulp yield for hardwoods are higher than softwoods and grasses. Yields of both samples are atop values reported in the literature (Fengel and Wegener 1984, Nwonwu 1997, González-Vila et al. 1999, Mân Vu et al. 2004, Ndukwe et al. 2009). The reduction of cooking time by 40 minutes marginally enhanced the total yield (about 1,5\%) of both samples. As expected, the percentage of rejects in pulps obtained at shorter pulp duration was higher than rejects from a cooking time of 70 minutes. As indicated in the percentages of rejects in Table 3, B. vulgaris was less affected by the length of pulping, probably owing to less lignification lignin in bamboo. Kappa number is an indication of residual lignin in pulp. It measures the degree of delignification achieved during pulping. Expectedly, a higher Kappa number was obtained in samples with shorter cooking times. The percentage active alkali (AA) consumption was largely unaffected by the length of pulping time.

Table 3. Pulping conditions and pulp characteistics.

\begin{tabular}{lrrrr} 
& \multicolumn{3}{c}{ Samples } \\
\cline { 2 - 3 } & \multicolumn{1}{c}{ B. vulgaris } & 30 & & G. arborea \\
\hline Cooking time (min) & 70 & 70 & 30 \\
\% Screened pulp Yield & 47,90 & 49,31 & 52,87 & 52,73 \\
\% Rejects & 0,10 & 0,46 & 0,04 & 1,38 \\
\% Total yield & 48,00 & 49,77 & 52,91 & 54,11 \\
Kappa number & 13,50 & 20,21 & 13,28 & 20,15 \\
Intrinsic viscosity (ml/g) & 606 & 606 & 667 & 667 \\
AA consumption (\%) & 98,55 & 98,43 & 98,44 & 98,14 \\
H-Factor & 1249 & 636 & 1249 & 636 \\
\hline
\end{tabular}




\section{Fibre dimensions}

The fibre dimensions and morphological indices of Nigerian gmelina and bamboo Kraft pulps are shown in Table 4. Gmelina has an average fibre length of $0,93 \mathrm{~mm}$. This is within the range $(0,7-3,0$ $\mathrm{mm}$ ) reported for most hardwoods (Fengel and Wegener 1984). In comparison with other non woody biomass, the fibre length of Nigerian bamboo is longer than rapeseed stalk, sunflower stalks, wheat straw, bagasse and cotton stalk with reported values of 1,$03 ; 1,70 ; 1,18 ; 0,83$ and $1,7 \mathrm{~mm}$, respectively (Mazhari Mousavi et al. 2013).In the same vein, it is even twice longer than reported values of switch grass and aspen fibre (Law et al. 2001). The fibre length of $B$. vulgaris $(2,1 \mathrm{~mm})$ is comparable with reported values for other bamboo species and some softwoods (typically 1-3mm for Scots-pine and Alsaka-cedar respectively) (Gort et al. 2009; Hon and Shiraishi 2001; Sharma et al. 2011; Abdul Khalil et al. 2012). The fibre length distributions of both samples depicted in Figure 1 shows that bamboo has a wider fibre length distribution than gmelina. While about $42 \%$ of gmelina fibre exists between $0,7-1,1$ $\mathrm{mm}$, where its length distribution peaked, only $20 \%$ is dispersed around a similar peak $(2,0-2,6 \mathrm{~mm})$ in bamboo fibres. Approximately $16 \%$ of the bamboo pulp has fibre length of was measured between $2,7-3,8 \mathrm{~mm}$.

The result of the fibre width distribution for both samples (Table 4) indicates that bamboo has more slender mean fibre width than gmelina and some aforementioned woody and non woody biomasses (Hon and Shiraishi 2001, Mazhari Mousavi et al. 2013). Similarly, the fibre width distribution curve (Figure 1) indicates a slightly narrower bamboo distribution than gmelina.

Table 4. Fibre characteristics of gmelina and bamboo pulps.

\begin{tabular}{lcc}
\hline Fibre Characteristics & Gmelina & Bamboo \\
\hline Number of analysed fibres & 10098 & 10077,3 \\
Fibre content, millions/g of pulp & 19,1 & 7,9 \\
Mean fibre arithmetic length, $\mu \mathrm{m}$ & 783,7 & 1358,3 \\
Mean length-weighted fibre length, $\mu \mathrm{m}$ & 934 & 2074 \\
Mean fibre width, $\mu \mathrm{m}$ & 24,1 & 16,9 \\
Cell wall thickness $(\mu \mathrm{m})$ & 3,6 & 4 \\
Mean fibre coarseness, mg/m & 0,1 & 0,1 \\
Slenderness ratio & 38,8 & 122,7 \\
Runkel ratio & 0,4 & 0,9 \\
Average kink number & 1,4 & 1,5 \\
Average kink angle, ${ }^{\circ}$ & 130,8 & 129,8 \\
Kinked fibre content, \% & 40,9 & 41,3 \\
Mean fibre curl index, $\%$ & 8,5 & 12,9 \\
Macro fibrillation index, $\%$ & 0,5 & 0,3 \\
Broken fibre content, $\%$ & 19 & 18 \\
Fines & 18633 & 70102 \\
Fines content, millions/g of pulp & 32,8 & 48,4 \\
Fine content, $\%$ in area & 3 & 3 \\
Fine content, \% in length & 14 & 23,5 \\
Mean fine area, $\mu m^{2}$ & 2344,3 & 2045 \\
Mean fine length, $\mu \mathrm{m}$ & 74,7 & 63,7 \\
Mean length, $\mu \mathrm{m}$ & 377 & 316,3 \\
\hline
\end{tabular}


A direct correlation exists between fibre morphology and paper properties (Ververis et al. 2004, Mazhari Mousavi et al. 2013). From the results of the slenderness ratio, paper obtained from bamboo will exhibit higher tear strength than that of gmelina. The average kink number, kink angle, kinked fibre content and broken fibre content of both materials were very similar. This observation implies that bamboo fibres were not significantly deformed in comparison to hardwood fibre under the same pulping condition. The mean fibre curl index of bamboo is considerably higher than gmelina's. This observation was not unanticipated considering the narrowness of the bamboo's fibre. The curliness of fibre can impact both the tensile index and tear strength of sheets obtained from the fibre. High fibre curl can cause low tensile index of the paper sheet, but with improved tear strength (Page and Seth 1980). Bamboo contains higher fine contents than gmelina. It can be seen in Table 4 that this difference emanates from variance in their fibre lengths. They both have the same fine content in area. The mean fine lengths of both samples were determined to be $316 \mu \mathrm{m}$ and $377 \mu \mathrm{m}$ respectively. From the above results, it can be deduced that bamboo fibre has higher breakability owing to a more brittle cell wall compared to gmelina. The amount of lignin in the non-woody biomass is significantly high, considering the maturation age of the plant in comparison to gmelina (hardwood). And this may be somewhat responsible for the brittleness of the fibre as previously noted by other authors (Abdul Khalil et al. 2012).
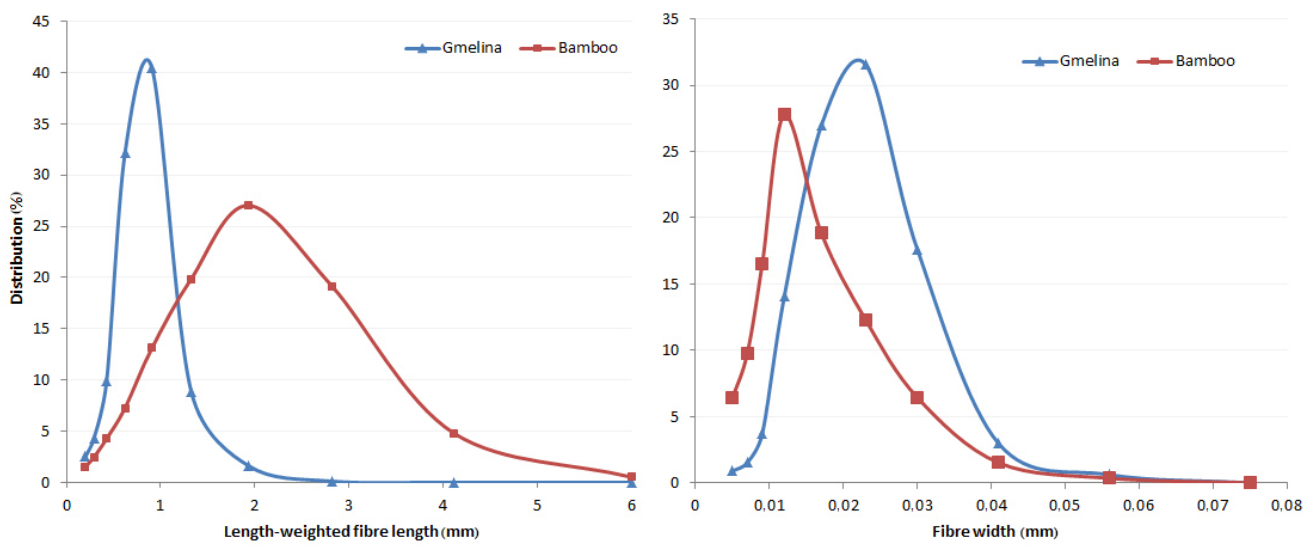

Figure 1: Fibre length and width distributions of gmelina and bamboo pulps.

The Runkel ratio is a parameter used in determining the suitability of a raw material for pulping (Kiaei et al. 2014). Raw materials with low Runkel ratio are preferred for paper making (Liese 1980, Kpikpi 1992, Ohshima et al. 2005). Woods suitable for pulping should have a Runkel ratio of less than one (Kpikpi 1992). The results of the Runkel ratio in Table 4 indicate that gmelina is though preferred; the values of both samples fall within desirable ratios for paper making.

\section{Paper properties}

In order to examine the paper properties of gmelina and bamboo, standard paper handsheet were produced from their pulps. The results of four paper properties obtained at different beatings for the two pulp samples are shown in Table 5. For the purpose of comparison, properties of handsheets from pulps of two common pulpwoods in South Africa, Eucalyptus grandis and Pinus paluta obtained through Kraft process, are also included in the Table. The results show that gmelina has a tensile index of $85 \mathrm{kN} . \mathrm{m} / \mathrm{kg}$ at a beating of 2000 revs. The beating between $1000-3000$ induced slight variation in the tensile index and papersheet density, but a marked improvement in these properties were obtained when compared to the unbeaten pulps. It can be said that the improvement in the tensile index and 
density is due to the straightening out of curled and kinked fibre through beating (Agnihotri et al. 2010, Sharma et al. 2011). Beating/refining increases fibre conformability, surface area and probability of interfibre bonding which leads to improved sheet properties such as tensile and sheet density. As previously observed above, there is great resemblance between the gmelina fibres and fibres from many hardwoods employed in paper production. It has been noted that resemblance between fibre dimension of pulpwoods and any pulpable material is not always a good predictor of the latter's paper properties (Ai and Tschirner 2010). However, in the case of gmelina hand sheets, all the measured paper properties are very similar to corresponding values obtained for South African hardwood (Eucalyptus grandis) pulps. The expected slight decline in the tear index at high beating is possibly due to fibrefibre bonding. Tear strength decreases when beating exceeds a certain point. This is due to fibre cutting and decreased fibre strength that accompanies excessive beating. However, this was not observed in gmelina compared to other samples in the Table 5.

Freeness is an important property of pulp that impacts drainage characteristics on paper machines. A typical acceptable value for papermaking ranges between 300 and $450 \mathrm{ml} \mathrm{CSF}$ (Shakhes et al. 2010). The results in Table 5 indicate that the freeness of both samples is indirectly proportional to the beating. This observation largely correlates with the findings of previous authors for other biomasses (Jahan et al. 2007; Dutt et al. 2010). Handsheets from bamboo on the other hand had a density of $585 \mathrm{~kg} / \mathrm{m}^{3}$ and tensile index of $56 \mathrm{kN} . \mathrm{m} / \mathrm{kg}$ at a beating of 3000 revs. Both values are lower than their corresponding values from gmelina handsheet. But the tensile index is comparable with $59,3 \mathrm{kN} . \mathrm{m} / \mathrm{kg}$ and $51,8 \mathrm{kN} . \mathrm{m} /$ $\mathrm{kg}$ values earlier reported for switchgrass and Miscanthus $x$ giganteus, both non-woody biomasses (Cappelletto et al. 2000, Law et al. 2001, Ai and Tschirner 2010).

Table 5: Paper properties of gmelina, bamboo and South African pulpwoods.

\begin{tabular}{lccccc}
\hline & $\begin{array}{c}\text { Beating } \\
\text { (revs) }\end{array}$ & $\begin{array}{c}\text { Freeness } \\
(\mathrm{CSF})\end{array}$ & $\begin{array}{c}\text { Tear Index } \\
\left(\mathrm{N} . \mathrm{m}^{2} / \mathrm{kg}\right)\end{array}$ & $\begin{array}{c}\text { Tensile Index } \\
(\mathrm{kN} . \mathrm{m} / \mathrm{kg})\end{array}$ & $\begin{array}{c}\text { Sheet } \\
\text { Density } \\
\left(\mathrm{kg} / \mathrm{m}^{3}\right)\end{array}$ \\
\cline { 1 - 4 } Gmelina - (KN 20) & 0 & 596 & 7 & 49 & 670 \\
& 1000 & 428 & 9 & 76 & 809 \\
& 2000 & 345 & 9 & 85 & 821 \\
& 3000 & 264 & 9 & 80 & 813 \\
Bamboo - (KN 20) & 0 & 695 & 15 & 30 & 462 \\
& 1000 & 606 & 23 & 41 & 508 \\
& 3000 & 451 & 20 & 56 & 585 \\
South African Hardwood & 5000 & 315 & 17 & 69 & 603 \\
Eucalyptus grandis - (KN 20) & & & & & \\
& 0 & 603 & 8 & 54 & 672 \\
& 1000 & 459 & 10 & 85 & 764 \\
South African softwood Pinus & 3000 & 302 & 9 & 103 & 838 \\
patula - (KN 30) & 5000 & 183 & 8 & 111 & 872 \\
& & & & & \\
& 1000 & 718 & 10 & 77 & 674 \\
& 2500 & 668 & 9 & 92 & 718 \\
& 5000 & 538 & 8 & 101 & 760 \\
& 7500 & 348 & 7 & 105 & 781 \\
\hline
\end{tabular}


Better still; the tear index of bamboo handsheets is three times higher than those of the aforementioned pulps of hardwood and softwood. This observation can be directly related to the narrowness of its fibre (tear is strongly correlated to fibre length) (Agnihotri et al. 2010, Sharma et al. 2011). Such fibres are suitable materials for the production of smooth surface paper sheets.

A plot of the tear index against tensile index for the two raw materials at different refining levels is shown in Figure 2. The result shows the variation in the plots of tear against tensile indices in different pulps. The bamboo largely compared to plots for softwoods and a great resemblance is established between previously reported hardwood (Scandinavian birch) curve and gmelina and Eucalyptus grandis (Seth 1991).

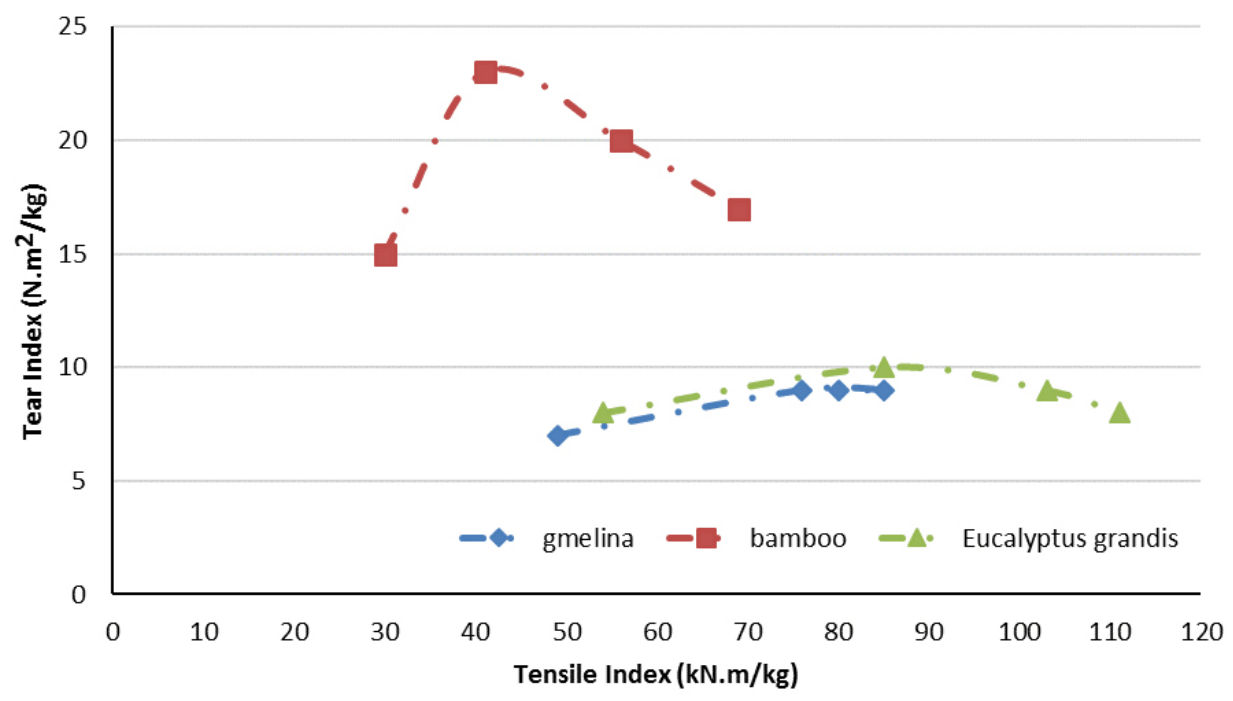

Figure 2: Tear index versus tensile index for bamboo, gmelina and Eucalyptus grandis.

\section{Paper properties of fibre blends}

The possibility of producing handsheets from blends of bamboo and gmelina fibres was explored. The hardwood pulp was mixed with bamboo pulp in the ratios of $3: 1,1: 1$ and 1:3. The resulting fibre mixtures were made into handsheets and their paper properties examined. The results of the various tests carried out are shown in figure 3. Of all the properties measured, density is mostly influenced by the blend composition. The sheet density $\left(809 \mathrm{~kg} / \mathrm{m}^{3}\right)$ of handsheet from pure gmelina fibre reduces by almost a quarter in handsheets containing equal amount of the two samples. The tear index of all blend compositions was significant improved from $8,9 \mathrm{kN} . \mathrm{m} / \mathrm{kg}$ to $16,4 \mathrm{kN} . \mathrm{m} / \mathrm{kg}$ in blends with three quarter bamboo fraction (This is expected as the percentage long fibres are increased). The fibre blend freeness was least influenced of all the measured properties. 


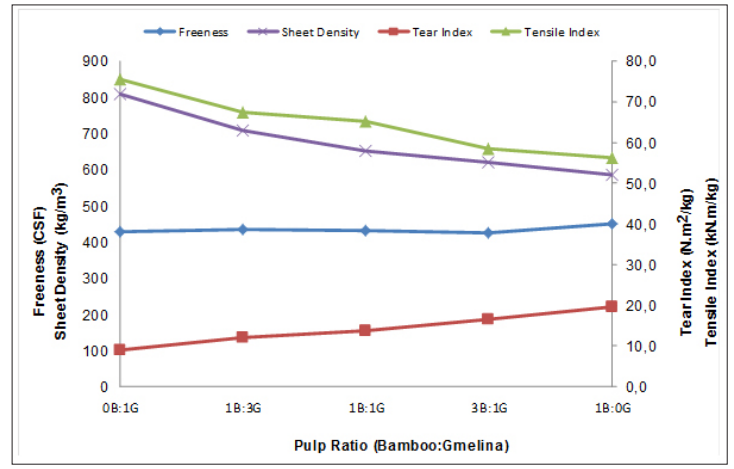

Figure 3: Influence of fibre blend on paper properties.

\section{CONCLUSIONS}

The chemical composition and fibre morphology of Nigerian-grown G. arborea and B. vulgaris, together with their pulping properties indicate that both biomasses are suitable materials for chemical pulping. Since the cooking conditions and the composition of gmelina and bamboo pulps are fairly similar, a co-cooking of both samples can be a convenient means of combining the samples into paper production. Consequently, a co-cooking of both samples could be explored in future test of these samples. Also, the result gives a positive indication on the possibility of producing paper from the blend of the two Nigerian-grown biomass materials. Handsheet of higher quality, in terms of tear index and sheet density, were obtained from blends of both samples, than paper prepared from single fibres.

\section{REFERENCES}

Abdul Khalil, H.P.S.; Bhat, I.U.H.; Jawaid, M.; Zaidon, A.; Hermawan, D.; Hadi, Y.S. 2012. Bamboo fibre reinforced biocomposites: A review. Materials \& Design 42: 353-368.

Agnihotri, S.; Dutt, D.; Tyagi, C.H. 2010. Complete characterization of bagasse of early species of Saccharum officinerum-CO 89003 for pulp and paper making. Bioresources 5 (2): 1197-1214.

Ai, J.; Tschirner, U. 2010. Fiber length and pulping characteristics of switchgrass, alfalfa stems, hybrid poplar and willow biomasses. Bioresource Technol 101(1): 215-221.

Akpabio, U.D.; Akpakpan, A.E. 2012. Pulp and paper from agricultural wastes: Plantain pseudostem waste and screw pine leaves. Int J Mod Chem 2(3): 100-107.

Akpakpan, A.E.; Akpabio, U.D.; Ogunsile, B.O.; Eduok, U.M. 2011. Influence of Cooking Variables on the Soda and Soda-Ethanol Pulpingof Nypa Fruticans Petioles. Aust J Bas Appl Sci 5(12): 1202-1208.

Ates, S,; NI, Y.; Akgul, M.; Tozluoglu, A. 2008. Characterization and evaluation of Paulownia elongota as a raw material for paper production. Afr J Biotechnol 7(22): 4153-4158.

Back, E.; Allen, L.H. 2000. Pitch Control, Wood Resin \& Deresination. TAPPI PRESS, Atlanta.

Cappelletto, P.; Mongardini, F.; Barberi, B.; Sannibale, M.; Brizzi, M.; Pignatelli, V. 2000. Papermaking pulps from the fibrous fraction of Miscanthus x Giganteus. Ind Crop Prod 11(2-3): 205210.

del Río, J.C.; Romero, J.; Gutiérrez, A. 2000. Analysis of pitch deposits produced in Kraft pulp mills using a totally chlorine free bleaching sequence. Journal of Chromatography A 874(2): 235-245.

Downes, G.M.; Hudson, I.L.; Raymond, C.A.; Dean, G.H.; Michell, A.J.; Schimleck, L.R.; 
Evans, R.; Muneri, A. 1997. Sampling plantation eucalypts for wood and fibre properties. CSIRO Publishing, Melbourne.

Dutt, D.; Upadhyaya, J.S.; Tyagi, C.H.2010. Studies on Hibiscus cannabinus, Hibiscus sabdariffa, and Cannabinus sativa pulp to be a substitute for softwood pulp- part 1: AS-AQ delignification process. Bioresources 5(4): 2123-2136.

Dvorak, W.S. 2004. World view of Gmelina arborea: opportunities and challenges. New Forests 28(2-3): 111-126.

Emerhi, E.A. 2012. Variation in anatomical properties of Rhizophora racemosa (Leechm) and Rhizophora harrisonii (G. mey) in a Nigerian mangrove forest ecosystem. Int J For Soil Eros 2(2): 89-96.

Fengel, D.; Wegener, G. 1984. Wood: Chemistry, Ultrastructure, Reactions. Walter de Gruyter \& Co., Berlin.

Fuwape, J.A. 1989. Gross heat of combustion of Gmelina (Gmelina arborea (Roxb)) chemical components. Biomass 19(4): 281-287.

Fuwape, J.A. 1993. Paper from kenaf fibre. Bioresource Technol 43(2):113-115.

González-Vila, F.J.; Almendros, G.; del Rio, J.C.; Martín, F.; Gutiérrez; A.; Romero, J. 1999. Ease of delignification assessment of wood from different Eucalyptus species by pyrolysis (TMAH)GC/MS and CP/MAS 13C-NMR spectrometry. J Anal Appl Pyrol 49(1-2): 295-305.

Gort, J.; Zubizarreta, G.A.; Peltola, H.; Pulkkinen, P.; Routa, J.; Jaatinen, R. 2009. Differences in fibre properties in Scots Pine (Pinus sylvestris L.) Genetic Entries grown at different spacing and sites. Silva Fennica 43(3): 355-368.

Hocking, M.B. 2005. Production of Pulp and Paper. In: Handbook of Chemical Technology and Pollution Control (Third Edition). Academic Press, San Diego, pp 453-504.

Hon, D.N.S.; Shiraishi, N. 2001. Wood and Cellulosic Chemistry. Marcel Dekker.

ISO. 2005. Pulps-Preparation of laboratory sheets for physical testing- Part 1: conventional sheet-former method ISO 5269-1. ISO Standard ISO Press, Geneva, Switzerland.

Jahan, M.S.; Islam, M.K.; Chowdhury, D.A.N.; Moeiz, S.M.I; Arman, U. 2007. Pulping and papermaking properties of pati (Typha). Ind Crop Prod 26(3): 259-264.

Khristova, P.; Kordsachia, O.; Patt, R.; Karar, I.; Khider, T. 2006. Environmentally friendly pulping and bleaching of bagasse. Ind Crop Prod 23(2): 131-139.

Kiaei, M.; Tajik, M.; Vaysi, R. 2014. Chemical and biometrical properties of plum wood and its application in pulp and paper production. Maderas- Cienc Tecnol 16(3): 313-322.

Kpikpi, W.M. 1992. Wood structure and paper-making potentials of Ricinodendron heudelotti and Albizia zygia in relation to Gmelina arborea. Niger J Bot 5(0): 41-50.

Law, K.N., Kokta, B.V.; Mao, C.B. 2001. Fibre morphology and soda-sulphite pulping of switchgrass. Bioresource Technol 77(1): 1-7.

Li, B.; Li, H.; Zha, Q.; Bandekar, R.; Alsaggaf, A.; Ni, Y. 2011. Review: Effects of wood quality and refining process on TMP pulp and paper quality. Bioresources 6(3): 3569-3584.

Li, X.B.; Shupe, T.R.; Peter, G.F.; Hse, C.Y.; Eberhardt, T.L. 2007. Chemical changes with maturation of the bamboo species Phyllostachys pubescens. J Trop For Sci 19(1):6-12.

Liese, W. 1980. Anatomy of bamboo. In: Lessard G, Chouinard A (eds) Bamboo research in Asia. International Workshop Singapore, Singapore.

Mân Vu, T.H.; Pakkanen, H.; Alén, R. 2004. Delignification of bamboo (Bambusa procera 
acher): Part 1. Kraft pulping and the subsequent oxygen delignification to pulp with a low Kappa number. Ind Crop Prod 19(1): 49-57.

Mazhari Mousavi, S.M.; Hosseini, S.Z.; Resalati, H.; Mahdavi, S.; Rasooly Garmaroody, E. 2013. Papermaking potential of rapeseed straw, a new agricultural-based fiber source. J Clean Prod 52(0): 420-424.

Ndukwe, N.A.; Jenmi, F.O.; Okiei, W.O.; Alo, B.I. 2009. Comparative study of percentage yield of pulp from various Nigerian wood species using the Kraft process. Afr J Environ Sci Technol 3(1): $21-25$

Nunes, C.A.; Lima, C.F.; Barbosa, L.C.A.; Colodette, J.L.; Gouveia, A.F.G.; Silvério, F.O. 2010. Determination of Eucalyptus spp lignin S/G ratio: A comparison between methods. Bioresource Technol 101(11):4056-4061.

Nwonwu, F.O.C. 1997. A comparison of Gmelina arborea yields in the derived and Guinea savanna zones of Nigeria. Discov Innov 9(3-4): 167-172.

Odeyemi, F. 1968. Kraft digestion of some Nigeria hardwoods. Comm Phys Maths 33 (11): 3-75.

Ogbonnaya, C.I. 1993. Effects of nitrogen sources on the wood properties of Gmelina arborea relevant to pulp and paper production. For Ecol Manage 56(1-4): 211-223.

Ogunkunle, A.T.J. 2010. A quantitative modelling of pulp and paper making suitability of Nigerian hardwood species. Adv Nat Appl Sci 4(1): 14-21.

Ogunkunle, A.T.J.; Oladele, F.A. 2008. Structural Dimensions and Paper Making Potentials of the Wood in Some Nigerian Species of Ficus L. (Moraceae). Adv Nat Appl Sci 2 (3): 103-111.

Ogunsile, B.O.; Uwajeh, C.F. 2009. Evaluation of the pulp and paper potentials of a Nigerian grown Bambusa vulgaris. World Appl Sci J 6(4): 536-541.

Ogunwusi, A.A. 2002. Wood properties of Sterculia setigera forming in the savanna belt of Nigeria. Niger J For 32(1): 50-55.

Ogunwusi, A.A 2011. Potentials of Bamboo in Nigeria's industrial sector. J Res Natl Dev 9 (2): 136-146.

Ogunwusi, A.A. 2012. Strategies for increasing pulp and paper capacities in Nigeria. Adv Agr Sci Eng Res 2(8): 306-317.

Ohshima, J.; Yokota, S.; Yoshizawa, N.; Ona, T. 2005. Examination of within-tree variations and the heights representing whole-tree values of derived wood properties for quasi-non-destructive breeding of Eucalyptus camaldulensis and Eucalyptus globulus as quality pulpwood. J Wood Sci 51(2):102-111.

Olatunji, G. 1999. Furanoresorcinol from the heartwood of Gmelina arborea. Cell Chem Technol 33(1-2): 37-39.

Onyekwelu, J.C. 2004. Above-ground biomass production and biomass equations for even-aged Gmelina arborea (ROXB) plantations in south-western Nigeria. Biomass Bioenerg 26 (1): 39-46.

Osadare, O.A. 1997. Strategies for long fibre pulp production in Nigeria. Niger J For 24(1-2): 16-20.

Page, D.H.; Seth, R.S. 1980. The elastic-modulus of paper-3. The effects of dislocations, microcompressions, curl, crimps, and kinks. Tappi 63(10): 99-102. 260.

Palmer, E.R. 1973. Gmelina arborea as a potential source of hardwood pulp. Trop Sci 15(3): 243-

Raji, J.A. 2007. Intercropping kenaf and cowpea. Afr J Biotechnol 6(24): 2807-2809. 
RMRDC. 2009. Raw Materials Sourcing for Manufacturing in Nigeria. vol $4^{\text {th }}$ Edition. Nigeria Raw Materials Research and Development Council, Abuja.

RMRDC. 2010. Technical Report of Assessment Visit to Nigeria Paper Mill, Jebba. Raw Materials Research and Development Council, Abuja.

Rowell, R.M. 2005. Handbook of Wood Chemistry and Wood Composites. CRC Press, New York.

Runge, T.; Heinricher, J.; Meier, D. 2014. Co-cooking moso bamboo with hardwoods. Tappi J 13(6):9.

Seth, R.S. 1991. Impliations of the single-ply Elmendorf tear strength test for characterizing pulps. Tappi J August edition: 109-113.

Shakhes, J.; Dehghani-Firouzabadi, M.R.; Rezayati-Charani, P.; Zeinaly, F. 2010. Evaluation of harvesting time effects and cultivars of kenaf on papermaking. BioResources 5(2):1268-1280.

Sharma, A.K.; Dutt, D.; Upadhyaya, J.S.; Roy, T.K. 2011. Anatomical, morphological, and chemical characterization of Bambusa tulda, Dendrocalamus hamiltonii, Bambusa balcooa, Malocana baccifera, Bambusa arundinacea and Eucalyptus tereticornis. Bioresources 6(4): 5062-5073.

Silva, T.C.F.; Gomide, J.L.; Santos, R.B. 2012. Evaluation of chemical composition and lignin structural features of Simarouba versicolor wood on its pulping performance. Bioresources 7(3): 39103920.

Sosanwo, O.; Lindberg, J.J. 1975. Gmelina arborea. I. Chemical composition of Nigerian Gmelina arborea wood species. Pap Puи 57(4A): 225-231.

TAPPI. 1988. Forming handsheets for physical tests of pulp T205-88. Test Method TAPPI Press, Atlanta, USA.

TAPPI. 1995. Determination of equilibrium moisture in pulp, paper and paperboard for chemical analysis. Test Method. TAPPI T550 om-93. TAPPI Press, Atlanta, USA.

TAPPI. 1999a. Carbohydrate composition of extractive free wood and wood pulp by gas- liquid chromatography. Test Method. TAPPI T249 om-94. TAPPI Press, Atlanta, USA.

TAPPI. 1999b. Freeness of Pulp (Canadian Standard Method) 2000-2001. Test Method. TAPPI T227. TAPPI Press, Atlanta, USA.

TAPPI. 2002a. Bursting strength of paper. Test Method. TAPPI 403. TAPPI Press, Atlanta, USA.

TAPPI. 2002b. Sampling and Preparing Wood for Analysis. Test Method. TAPPI. T257 cm-02. TAPPI Press, Atlanta, USA.

TAPPI. 2004a. Internal Tearing Resistance of Paper (Elmendorf-Type Method). Test Method. TAPPI T 414 om-04. TAPPI Press, Atlanta, USA.

TAPPI. 2004b. Solvent extractives of wood and pulp. Test Method. TAPPI T $204 \mathrm{~cm}-97$. TAPPI Press, Atlanta, USA.

TAPPI. 2006a. Kappa number of pulp. Test Method. TAPPI T 236 om-06. TAPPI Press, Atlanta, USA.

TAPPI. 2006b. Tensile Properties of Paper and Paperboard (Using Constant Rate of Elongation Apparatus). Test Method. TAPPI T 494 om-06. TAPPI Press, Atlanta, USA.

Udohitinah, J.S.; Oluwadare, A.O. 2011. Pulping properties of Kraft pulp of Nigerian-grown kenaf (Hibiscus cannabinus L.). Bioresources 6(1): 751-761.

Ververis, C.; Georghiou, K.; Christodoulakis, N.; Santas, P.; Santas, R. 2004. Fiber dimensions, lignin and cellulose content of various plant materials and their suitability for paper production. Ind Crop Prod 19(3): 245-254. 